\title{
Clinical comparison of the Keeler Pulsair 3000 with Goldmann applanation tonometry
}

\author{
V A Parker, J Herrtage, N J C Sarkies
}

\begin{abstract}
Aim-To confirm the accuracy of the Pulsair 3000 before introducing the instrument into clinical practice.

Method-A masked study by two experienced tonometrists comparing the mean of the Goldmann intraocular pressure (IOP) readings against the Pulsair 3000 reading (average of four puffs). Results of 150 eyes were compared with an IOP range of $10 \mathrm{~mm} \mathrm{Hg}-44 \mathrm{~mm} \mathrm{Hg}$.

Results-Correlation between the two Goldmann tonometry results was 0.9830 with a standard deviation of $1.1085 \mathrm{~mm}$ Hg. Correlation between the mean of the two Goldmann readings against the Pulsair 3000 reading was 0.982 with a standard deviation of $1.1179 \mathrm{~mm} \mathrm{Hg}$. BlandAltman analysis confirms a satisfactory outcome.

Conclusion-The Pulsair 3000 provides an accurate and objective method of measuring IOP with many advantages over traditional Goldmann tonometry.

(Br f Ophthalmol 2001;85:1303-1304)
\end{abstract}

The original Pulsair Mark 1 was launched in 1986 in an attempt to provide a portable, hand held and non-contact form of tonometry. Many studies were undertaken to compare this new method with standard Goldmann tonometry. It was generally accepted that this model could provide clinically useful measurements of intraocular pressure (IOP) but there were concerns that low pressures were being overestimated and high pressures underestimated. ${ }^{1}$ Another study concluded that the Pulsair read too low across the entire range. ${ }^{2}$

The benefits of the Pulsair, however, included patient preference, less operator dependence, and no risk of transmission of infection-for example, herpes, adenovirus, or the transmissible agent causing CreutzfeldtJakob disease. ${ }^{3}$

Improvements in electronics and software techniques led to the development of the Pulsair 2000 launched in 1991. The Pulsair 2000 allowed the averaging of the four readings to be done automatically with a review facility displaying individual readings. It also included automatic switching into high pressure mode if an IOP is greater than $30 \mathrm{~mm} \mathrm{Hg}$. Studies using the Pulsair 2000 showed that it could accurately predict Goldmann IOPs ${ }^{4}$ and that it passed the British standard for reproducibility of a standard test method. ${ }^{56}$

The Keeler Pulsair 3000 became available in November 1998 following a lengthy development programme to improve upon the Pulsair 2000. Improvements include an air delivery system that accurately controls the amount of air delivered to the eye enabling a precise, repeatable puff producing precise and repeatable readings with less discomfort to the patient. Software improvements have made the instrument easier to use with prompts and error messages ensuring accurate results.

Clinical proof of the accuracy of the Pulsair 3000 was required before introducing the instrument into our clinics.

\section{Methods}

Two experienced Goldmann tonometrists performed a masked study of 150 eyes. The mean pressure of the 150 eyes tested by tonometrist no 1 was $21.06 \mathrm{~mm} \mathrm{Hg}$ and by tonometrist no 2 was $21.17 \mathrm{~mm} \mathrm{Hg}$. In order to cover a comprehensive range of IOP we included no less than 40 eyes in each of the following pressure groups: 7-18 $\mathrm{mm} \mathrm{Hg},>18-24 \mathrm{~mm} \mathrm{Hg}$, and $>24 \mathrm{~mm} \mathrm{Hg}$. The total range was $10-44 \mathrm{~mm}$ $\mathrm{Hg}$. These ranges were chosen according to the International Standards Organisation draft standard on tonometers.

Subjects were selected from glaucoma clinics according to the following exclusion criteria:

(1) High corneal astigmatism - that is, those eyes displaying an oval contact image with the Goldmann tonometer

(2) Corneal scarring or corneal surgery including corneal laser surgery

(3) Microphthalmos

(4) Buphthalmos

(5) Blepharospasm

(6) Manifest nystagmus

(7) Keratoconus

(8) Known corneal or conjunctival infection.

Both Goldmann tonometers were calibrated at the beginning of each session and the results of tonometrist no 1 were unknown to tonometrist no 2 until the end of each session. The Pulsair 3000 test was performed by tonometrist no 1 after the first Goldmann reading. The Pulsair provides a digital readout of the IOP, therefore prior knowledge of the Goldmann result could not influence the result. The average of four puffs was used in the study. The second Goldmann reading was taken by tonometrist no 2 with as little delay as possible between the reading (average 20 minutes). One Goldmann reading only was taken by each tonometrist to avoid the tendency for IOP to decrease on multiple testing. ${ }^{7}$

\section{Results}

Correlation between the first and second Goldmann readings was 0.9830 with a standard deviation of $1.1085 \mathrm{~mm} \mathrm{Hg}$.

The mean of the two Goldmann readings was used in comparison with the Pulsair 3000 


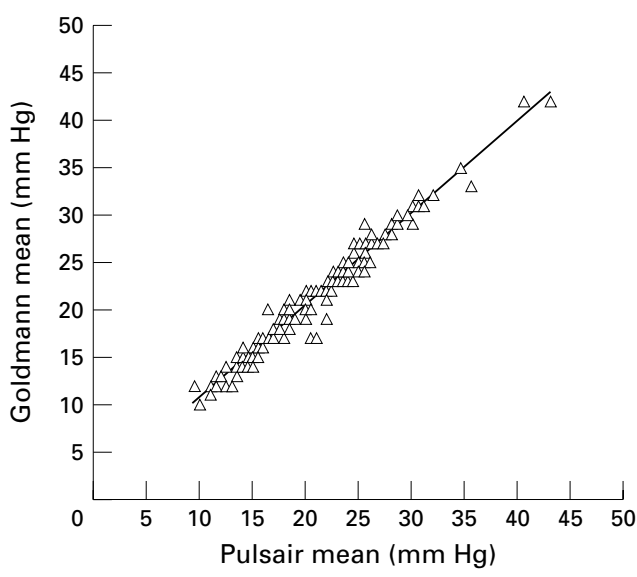

Figure 1 Correlation between Goldmann mean and Pulsair mean.

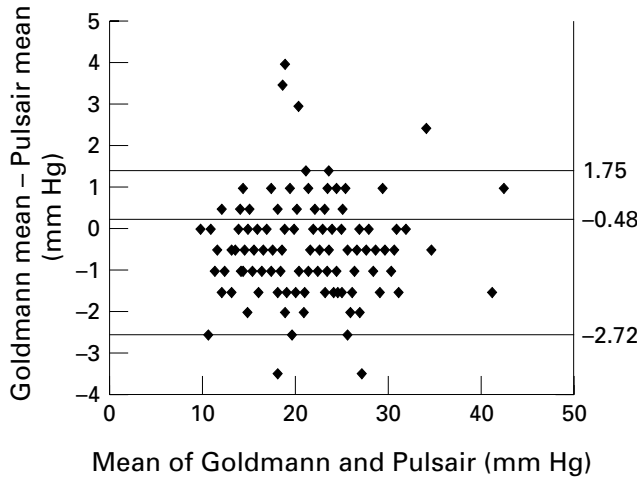

Figure 2 Bland-Altman analysis.

result (average of four puffs). The correlation was 0.982 with a standard deviation of 1.1179 $\mathrm{mm} \mathrm{Hg}$.

Clinically, it is important to prove that the Pulsair could replace applanation tonometry or the two methods could be interchangeable. Therefore, a further and more appropriate statistical analysis would be to use the BlandAltman method. ${ }^{8}$ Rather than simply plotting the results of one method against those of another, a plot of the difference between the methods against their mean would be more informative; $95 \%$ of the differences should be less than two standard deviations from the mean difference in order for the instrument to be acceptable.

The numbers on the figure show the mean difference $(-0.48)$ and the mean difference plus or minus 2 standard deviations of the differences $(-2.72$ and 1.75$)$.

This shows that $95 \%$ of Pulsair 3000 results fall between 1.75 and $-2.72 \mathrm{~mm} \mathrm{Hg}$ with a mean value of $0.48 \mathrm{~mm} \mathrm{Hg}$ compared with the Goldmann average.

If the same method is used to analyse the two Goldmann readings it shows that $95 \%$ of the results fall between 2.10 and $-2.33 \mathrm{~mm} \mathrm{Hg}$ with a mean value of $-0.11 \mathrm{~mm} \mathrm{Hg}$.

\section{Discussion}

The results of this study show that the Pulsair 3000 has been accurately calibrated to within an acceptable margin of error. There is little difference between the correlation of the two Goldmann readings compared with the correlation of Pulsair against the Goldmann mean. ${ }^{9}$ The results using the Bland-Altman method also show good agreement and that the Pulsair shows acceptable readings on comparison with Goldmann tonometry.

The changes to the Pulsair have produced a user friendlier instrument for the operator and less discomfort to the patient. Advantages include removing the need for local anaesthetic and fluorescein drops and no risk of corneal abrasion or cross infection.

With practice, the Pulsair can provide an accurate measurement of IOP within approximately 20 seconds per eye and eradicates most operator influences or error.

The Pulsair 3000 is hand held and portable and is very useful clinically when testing wheelchair bound or immobile patients. It has also been used on many occasions in our clinic to test the IOP of babies and children avoiding the need for general anaesthesia.

In conclusion, the Pulsair 3000 is as accurate as Goldmann tonometry in the population studied and has distinct advantages.

The authors have no financial interest in the Pulsair 3000

1 Moseley MJ, Evans NM, Fielder AR. Comparison of a new non-contact tonometer with Goldmann applanation. Eye 1989;3:332-7

2 Brencher HL, Kohl P, Reinke AR, et al. Clinical comparison of air-puff and Goldmann tonometers. $\mathcal{F}$ Am Optom Assoc 1991;62:395-402.

3 Rizzo M, Corbett JJ, Thompson HS. Is applanation tonometry a risk factor for transmission of Creutzfeldt-Jakob disease? Arch Ophthalmol 1987;105:314.

4 Wingert TA, Bassi CJ, McAlister WH, et al. Clinical evaluation of five portable tonometers. F Am Optom Assoc 1995;66:670-4.

5 British Standards Institution. Precision of test methods 1: Guide for the determination and reproducibility for a standard test method (BS 5497, part 1). London: BSI, 1979 .

6 Vernon SA. Reproducibility with the Keeler Pulsair 2000 non-contact tonometer. Br f Ophthalmol 1995;79:554-7.

7 Wilke K. Effects of repeated tonometry: genuine and sham Wilke K. Effects of repeated tonometry: genuine
measurements. Acta Ophthalmol 1972;50:574-82.

8 Bland JM, Altman DG. Statistical methods for assessing agreement between two methods of clinical measurement. Lancet 1986;i:307-10.

9 Kass M. Standardizing the measurement of intraocular pressure for clinical research. Ophthalmology 1996;103: 